are now scattered, and sending them back to their native land seems the best, for there, at least, they may have a chance of being identified and taken by some relatives who in time might adopt them.

The condition of the poor refugees, as they are sent north to relieve the crowded conditions in the south, is often pitiful, for in some cases they are not sufficiently clad and are almost famished, having been given but one small piece of bread in the twelve hours between Naples and Florence. Does this seem right with all the money that was subscribed and all the clothing which was sent?

Committees of ladies meet the trains as they go through Florence and provide what food and clothing they have on hand. The poor wretches are most homesick, and it is doubtful if they can be made contented and willing to settle down and work in the northern cities. Perhaps later on they can be sent back to their beloved Sicily or Calabria, for they are truly children of the soil and do not bear transplanting.

\title{
ANOTHER LETTER FROM NAPLES
}

[Our readers will remember that an interesting letter from a Henry Street Settlement nurse, who was in Italy at the time of the earthquake, was given in the editorial department of the February Joursal. The following extracts are from more recent letters by the same writer.-ED.]

Hotel Beilevue, Naples.

You must have another line for I feel you are interested. Order, of a sort, is appearing out of the chaos, and with a few self-imposed rules, so I shall not get tired, I'm going strong.

The improvised operating room is the wonder of the place. A tiny coil of pipe over a gas flame gives a supply of hot water, and a gas stove, one burner, is used to sterilize dressings and instruments-and it's all surgical work! Such dressings! A stream of doctors all day long. 'Tetanus serum has been used in quantities. There isn't a bit of sterilized catgut in the place. ...

The ladies in the hotel give me clothes every day after dinner, and I go to bed early and take them in a suit case in the morning. I tried to explain who I was. The result is that I am one of the first "nurses settled" in America, and a Signora Inglese of the well-known house of Richmond.

The tragedy, thank God, is lifting a little bit. We are a comic opera lot in our improvised get ups. A woman had wept on my shoulder over the loss of her daughter's betrothed, who had been their sole sup- 
port for a long time. A tiny man in an English shooting coat and knickerbockere (made for a six-footer), bandaged legs, and white tennis shoes, appeared at the door. Joyful screams of recognition. Lo, the daughter's betrothed!

One of my ablest assistants is a refugee in white cricketing flannels and dancing pumps. The hands and faces of all have been washed at last. The patients on special diets, nearly all, get something approximating the stuff ordered. The kind ladies and gentlemen who come and start feeding the multiple abscess case meat and macaroni need dealing with gently.

Tell - all her safety-pins went to the hospital. Tell Miss I wish she'd tell me what to do when the Consiglia Provincealc de Napoli send by messenger a vote of thanks on most important looking paper.

I think another ten days will see us out of the woods.

Dear Head NuRse:

NAPLES, February 3rd.

Still here, you see, but expect to finish to-morrow. For example, this morning two Sisters went to one of the convents of the Sisters of Charity. One woman went to relations, in a nearby village. Har father, and two lonely old ladies, to the Madonna del'Arco, a sort of workhouse, poor souls. One other went to a hospital for nervous diseases. They are getting assimilated after this fashion, more or less. Mrs. —_'s doctor called last night and gave me two barrels of sugar. My special work has been getting the generous gifts from the giver to the recipient. I got a man and a rope, and a frail cart for the sugar this morning before starting for the hospital; had to pay him five shillings too. Dr. — gave me 100 lire for a family who are every one of them a mass of surgical dressings. I know the doctors who do the dressings—oh, it's a terribly needy affair. The doctor got my last 50 lire (of refugee money) for the cases. Dr. — also unloaded a sterilizer on me. I told him they fed the youngsters on bread and wine, and the best I could do was to present it to a hospital, if they would accept it. So I will have to take a carriage and take the white elephant along, for he said he was quite willing to leave it to my something-orother. He brought it with him to my hotel. I hope you see the funny side of all this.

Please tell Miss - that the sugar has been accepted with gratitude by the hospital and will be used for the insene rescued at Messina besides the emergency refugees. 
There is one thing about the work over here I have discovered with surprise; no matter how much muddle and confusion-ten incapable people to do the work of one ordinary worker, and so on-there is no tension. That strained snapping-point moment that we all know, and dread, is not. It does not exist. "What must I do?" "What God wills." They say this and it seems to have soaked through every-day life. "I am the Master of my fate," "I am the Captain of my soul?" Not at all, say they, that way leads to nervous prostration, it's too much responsibility. "Molto Stentura" (misfortune) has Italy, but it.never crushes her.

\section{HOUSEHOLD HYGIENE}

\section{By ISABEL MCISAAC}

I.

THE SITE OF THE HOOSE

A sciEntist recently said, "A good housekeeper is a woman who understands cooking and bacteriology;" which at first thought seems a narrow range of intelligence, but when one grasps the principles of chemistry concerned in cooking and the principles of bacteriology, it is soon very evident that the two sciences cover enormous fields, which include the simplest domestic duty as well as the most elaborate preparations for surgery.

Incredible as it may appear, there are still persons who criticise the teaching of bacteriology to nurses, but in spite of their protests the teaching has steadily increased, and there is every reason for thinking that within ten years bacteriology will be taught as much or more in every public school in the country.

Any woman who is at all familiar with good housekeeping cannot fail to be impressed, when she takes up bacteriology, with the really good technic which has prevailed in well-ordered households for generations; the cleanliness of food, clothing and furnishings was perhaps due to the resthetic sense of our grandmothers, but some of us can recall hearing them express themselves, before the germ theory of disease was known outside of Pasteur's laboratory, upon the sources of infection in tuberculosis and child-bed fever and upon the dangers from disease lurking in unclean beds and dish-towels. Their observance of the time-honored rite of house cleaning, especially in the spring, after the "shut-up" season, was not instituted upon any scientific knowledge they possessed, but certainly speaks volumes upon their insight into cause and effect. 